\title{
THE SIMPLE IS-LM MODEL WITH CREDIT RATIONING
}

\author{
Roland Buck, Morehead State University ${ }^{l}$
}

\begin{abstract}
This paper examines how the effects of credit rationing can be incorporated into the simple IS-LM model. When credit rationing occurs, firms are not able to sell all the bonds they desire at the current rate of interest. Therefore transactions take place and are finalized at a price at which the implicit bond market underlying the model fails to clear. The non-market-clearing analysis derived from Clower's dual decision hypothesis is used to analyze the impact of such non-market-clearing transactions on the IS and LM curves.
\end{abstract}

\section{INTRODUCTION}

Over 65 years have now passed since Hicks [8] first introduced the IS-LM model into the literature. In spite of the extensive criticism to which the model has been subjected on many different grounds, it continues to survive, both as an expository device and as an analytical tool. For example, Fischer [6, p. 35] has stated: “...it's still the basic model that people use - in fact I use it - in understanding the economy. ...I don't think that there is a better model for getting the intuition of the short-run adjustment of the economy right." Therefore it is essential that the model's properties be fully understood.

One of the features of the simple IS-LM model (that is, the version without an explicit labor market and a production function added to it) is that while it contains markets for commodities, money, and bonds (or credit), only the commodity and money markets are included in the explicit analysis. This raises the question of what the properties of the implicit bond market underlying the model are and how this market interacts with the money and commodity markets.

It has been shown in the literature that Walras' Law can be used to place a bond market equilibrium curve between the IS and LM curve, like the BB curve in Figure $1 .^{2}$ However, when credit rationing occurs transactions take place and are finalized when the implicit bond market underlying the model does not clear, that is, at points below this BB curve, a condition under which Walras' Law (which is based on the assumption of market clearing) does not hold. Therefore the properties of the model under conditions of credit rationing must be derived using an approach that explicitly permits transactions to take place and be finalized at prices at which markets do not clear. This can be done by making use of the non-market-clearing analysis based on the dual decision hypothesis developed by Clower [4]. This approach, as developed in the 1970s by Grossman [7] and Barro and Grossman [1], specifically analyzes the impact of non-market-clearing transactions in one market on all the other markets. We shall use it in this context to analyze the effects of credit rationing on the various markets in the model. ${ }^{3}$ In addition to examining the relationship of the impact of credit rationing on the various markets in the model, a second objective of this paper is to demonstrate the continuing relevance of the non- 
market-clearing analysis derived using Clower's dual decision hypothesis to macroeconomic modeling.

\section{A SIMPLE IS-LM MODEL}

In order to analyze the effects of credit rationing on the model we at this point specify a simple textbook version of the IS-LM model. In order to be able to analyze the interaction between the bond market, in which the credit rationing takes place, and the commodity market, the model must be specified in such a manner that changes in the stock of bonds and flows in the commodity market can interact at the relevant point in time. Therefore we specify a discrete end-of-period stock-flow version of the simple textbook model. It is important to note however that the analysis holds for any specification that permits changes in the stock of bonds and flows in the commodity market to interact at the relevant point in time. For example, the results also hold if the model is specified on a continuous pure flow basis, in which the supplies and demands for money and bonds are for instantaneous changes in the levels of asset holdings, as is done, for example, in the model in Grossman [7]. However, since the supply and demand for money in the simple IS-LM model are normally specified to be supplies and demands for stocks at a point in time, the endof-period stock-flow specification is more appropriate.

The model confines itself to a single period of time. All markets explicitly included in the model are assumed to have cleared at the end of the previous period. There are two assets: money in the form of currency issued by the government and bonds issued by firms. The government issued the money during previous periods and does not change the money supply during the current period. Therefore the government sector can be omitted from the model and the supply of money at the end of the period is equal to the stock of money at the beginning of the period. The bonds are fixed-price, variable-coupon bonds that pay the rate of interest $r$. Firms pay out all of their profits to the household sector. Firms are assumed to purchase their investment goods from other firms, rather than producing these goods themselves. In consistency with the simple IS-LM model, it is assumed that the price level does not change during the current period. Therefore adjustment in the commodity market during the current period is brought about by adjustment in output. The model also makes the standard assumption made in the simple model that firms seek to sell the amount that they produce during the current period, so that the actual output produced represents aggregate supply, and therefore no separate aggregate supply function is required. The output produced is identical to the income generated, so that aggregate supply and aggregate income are identical. They will both be represented by the symbol Y.

The model assumes that transactors make all transactions plans for the current period at the beginning of the period. In addition, all sales and purchases for the period are completed at the beginning of the period, but all deliveries and payments take place at a constant rate throughout the period. In the commodity market transactors' plans are made with respect to the desired total values of the flows over the period and all variables represent the integrals of the flows from the beginning of the period to the end of the period. In the money and bond markets, since they are markets for stock aggregates, transactors' plans are made with respect to the total amount of these assets that they wish to hold or have issued at the end of the period, and supplies and demands are therefore in terms of such desired end-ofperiod stocks. It is assumed that transactors desire to adjust their beginning-of-period assets to their desired end-of-period supplies and demands at a constant rate during the period, which results in flow supplies and demands for changes in the holdings of 
money and bonds during the period. It follows that changes in the money holdings of transactors must also take place continuously at a constant rate.

$\mathrm{We}$, at this point, specify a version of the model with notional supplies and demands based on the assumption that transactors expect to succeed in carrying out their transactions plans and derive notional market equilibrium curves from them. ${ }^{4}$ This model will serve as a benchmark against which the non-market-clearing results derived below can be compared.

The notional supplies and demands are as follows:

Consumption

$$
C^{D^{*}}=C^{D^{*}}\left(Y^{*}\right), \quad 0<\left(C^{D^{*}}\right)_{Y^{*}}<1 .
$$

Since firms desire to sell the amount that they produce during the current period, $\mathrm{Y}^{*}$ represents notional aggregate supply. In the absence of taxes, this is identical to the appropriate income term in the consumption function.

Investment

$$
I^{D^{*}}=I^{D^{*}}(r), \quad\left(I^{D^{*}}\right)_{r}<0,
$$

where $r$ is the rate of interest.

Aggregate demand for commodities

$$
Y^{D^{*}} \equiv C^{D^{*}}+I^{D^{*}} .
$$

Money demand

$$
\begin{array}{r}
M_{t+1}^{D^{*}} \equiv M_{t+1}^{h, D^{*}}\left(r, Y^{*}\right)+M_{t+1}^{f, D^{*}}\left(r, Y^{*}\right),\left(M_{t+1}^{h, D^{*}}\right)_{r}<0, \quad\left(M_{t+1}^{h, D^{*}}\right)_{Y^{*}}>0 \\
\left(M_{t+1}^{f, D^{*}}\right)_{r}<0, \quad\left(M_{t+1}^{f, D^{*}}\right)_{Y^{*}}>0
\end{array}
$$

Money supply

$$
M_{t+1}^{S^{*}} \equiv M_{t} \equiv M_{t}^{h}+M_{t}^{f} .
$$

The notation in all equations in this paper follows the following rules: Stocks with a " $t$ " subscript are beginning of period while stocks with a $t+1$ subscript are end of period. $\mathrm{M}^{\mathrm{h}}$ represents the money balances held by the household sector and $\mathrm{M}^{\mathrm{f}}$ represents the money balances held by the firm sector. Terms with D superscripts 
represent demands, and terms with $\mathrm{S}$ superscripts represent supplies. The asterisk indicates that they are notional supplies and demands. Terms without $\mathrm{D}$ or $\mathrm{S}$ superscripts represent realized quantities. ${ }^{5}$ Therefore, for example, $M_{t+1}^{\mathrm{h}, \mathrm{D}^{*}}$ is the notional demand for money of the household sector at the end of the period, and $\mathrm{M}_{\mathrm{t}}^{\mathrm{f}}$ is the amount of money held by the firm sector at the beginning of the period. Subscripts after parentheses represent derivatives or partial derivatives.

The notional commodity market equilibrium curve, IS*, indicates all combinations of $r$ and $\mathrm{Y}$ at which

$$
Y^{D^{*}}-Y^{*}=0
$$

The notional money market equilibrium curve, $\mathrm{LM}^{*}$, indicates all combinations of $\mathrm{r}$ and $\mathrm{Y}$ at which

$$
M_{t+1}^{D^{*}}-M_{t+1}^{S^{*}}=0
$$

A notional bond market equilibrium curve, $\mathrm{BB}^{*}$, will now be added to the model, which indicates all combinations of $\mathrm{r}$ and $\mathrm{Y}$ at which

$$
B_{t+1}^{D^{*}}-B_{t+1}^{S^{*}}=0
$$

so that the bond market clears. $\mathrm{B}^{\mathrm{D}}$ is the demand for bonds and $\mathrm{B}^{\mathrm{S}}$ is the supply of bonds. Therefore, for example, $\mathrm{B}_{\mathrm{t}+1}^{\mathrm{D}^{*}}$ represents the notional demand for bonds at the end of the period.

Since the demand and supply of bonds are not explicitly specified in the model, we derive this curve using notional budget constraints for the household and firm sectors. The notional constraint of the household sector is

$$
\left(Y^{*}-C^{D^{*}}\right) \equiv\left(M_{t+1}^{h, D^{*}}-M_{t}^{h}\right)+\left(B_{t+1}^{D^{*}}-B_{t}\right)
$$

The notional demand for bonds is derived from equation (9). It is

$$
B_{t+1}^{D^{*}} \equiv B_{t}+Y^{*}-C^{D^{*}}-\left(M_{t+1}^{h, D^{*}}-M_{t}^{h}\right)
$$

The notional constraint of the firm sector is 


$$
\left(B_{t+1}^{S^{*}}-B_{t}\right) \equiv I^{D^{*}}+\left(M_{t+1}^{f, D^{*}}-M_{t}^{f}\right) .
$$

[Note that this constraint permits firms to finance notional investment either out of bonds or by drawing down money balances. However, since the notional demand for money in equation (4) does not include investment as an argument, the notional investment is being financed out of bonds.] The notional supply of bonds is derived from equation (11) and is

$$
B_{t+1}^{S^{*}} \equiv B_{t}+I^{D^{*}}+\left(M_{t+1}^{f, D^{*}}-M_{t}^{f}\right)
$$

Subtraction of equation (12) from equation (10), using equations (3), (4) and (5) gives us Walras' Law for the notional excess demands:

$$
\left(B_{t+1}^{D^{*}}-B_{t+1}^{S^{*}}\right)+\left(Y^{D^{*}}-Y^{*}\right)+\left(M_{t+1}^{D^{*}}-M_{t+1}^{S^{*}}\right) \equiv 0 .
$$

Therefore Walras' Law correctly shows the relationship of the notional excess demands to each other. Walras' Law can then be used to place the $\mathrm{BB}^{*}$ curve into the model. It lies between the IS ${ }^{*}$ and $\mathrm{LM}^{*}$ curves, like in Figure 2, with all of the curves being notional market equilibrium curves. ${ }^{6}$ Depending on the values of the parameters, it can slope either upward or downward to the right.

If the model is specified in a manner such that no transactions are allowed to take place and be finalized when any of the markets do not clear, the notional demands, supplies and market equilibrium curves are the relevant ones that indicate the sources of market pressure on the markets. In that case the notional market equilibrium curves are the effective market equilibrium curves, as shown in Figure 1. However when credit rationing takes place transactions take place and are finalized at a rate of interest at which the bond market does not clear. ${ }^{7}$ As a result, there will be spillovers from the effects of such non-market-clearing transactions into at least one of the other markets and therefore a non-market-clearing version of the IS-LM model is needed to analyze the implications of the credit rationing for the other markets.

\section{THE MODEL WITH A NON-CLEARING BOND MARKET}

We now specify a model in which credit rationing takes place. Since credit rationing involves a condition of excess demand for credit, this implies a condition of excess supply in the bond market It is still assumed that all markets had cleared during the previous period, so that general equilibrium had prevailed. In addition, it is assumed that the rate of interest at the beginning of the current period is below the level at which the bond market clears ${ }^{8}$ and remains unchanged during the current period (adjusting only in one or more subsequent periods) and that transactions will take place and be finalized under such conditions. (However, all that is necessary for the results to hold is for the rate of interest to adjust too slowly during the current period to clear the bond market; that is, that it is a sticky price.)

In order to concentrate on the implications of non-market-clearing transactions in the bond market, it will be assumed that firms instantaneously adjust 
their output to equal the effective aggregate demand for commodities at the beginning of the period, so that the commodity market continuously clears, and that no transitions take place until this has occurred. ${ }^{9}$ Therefore there no spillovers from any non-market-clearing transactions in the commodity market into any of the other markets. In addition, it must be noted that while the money market is a market in the sense that the term is used in redundant market analysis - that there is a demand function for money, a supply function for money, and an equilibrium condition that equates the quantities of money supplied and demanded - there is no money market in the sense of a trading post at which money is traded and a price of money is established. (The rate of interest is established in the bond market by the supply and demand for bonds.) Therefore there can be no spillovers into the other markets as a result of non-market-clearing transactions in the money market.

When transactions take place and are finalized in the bond market when it does not clear, spillovers from this market into at least on of the other markets will occur so that at least some of the notional supplies and/or demands will not be the relevant supplies and demands that actually manifest themselves in their respective markets when transactors attempt to carry out their transactions plans. Therefore, effective supplies, demands, and market equilibrium curves that take these spillovers into explicit account must be derived. Such effective market equilibrium curves will correctly show the sources of market pressure in such markets under such conditions. Since the money supply at the end of the period is predetermined, it is both effective and notional so that equation (5) becomes:

$$
M_{t+1}^{S} \equiv M_{t} \equiv M_{t}^{h}+M_{t}^{f}
$$

Supplies and demands that have neither an asterisk nor a prime are both effective and notional.

Since the household sector is a demander of bonds, it always succeeds in carrying out its transactions plans in the bond market under conditions of excess supply. Therefore the household sector demand for commodities is effective as well as notional. In addition, since the assumption that firms desire to sell their current output during the current period is not altered by any spillover from the bond market, the current output produced, Y, represents the effective, as well as the notional, aggregate supply of commodities, so that equation (1) becomes:

$$
C^{D}=C^{D}(Y)
$$

Since the household sector can continue to carry out its transaction plans, the notional household sector constraint is also the effective constraint and is

$$
\left(Y-C^{D}\right) \equiv\left(M_{t+1}^{h, D}-M_{t}^{h}\right)+\left(B_{t+1}^{D}-B_{t}\right)
$$

The notional and effective demand for bonds is derived from equation (9.1), and is 


$$
B_{t+1}^{D} \equiv B_{t}+Y-C^{D}-\left(M_{t+1}^{h, D}-M_{t}^{h}\right)
$$

Since the commodity market always clears, so that there are no spillovers from nonmarket-clearing transactions in the commodity market and, since there are no spillover from non-market-clearing transactions in the money market, it follows that with respect to the impact of realized transactions in the commodity market on the other markets the notional firm sector constraint is also the effective constraint, so that equation (11) becomes:

$$
\left(B_{t+1}^{S}-B_{t}\right) \equiv I^{D^{*}}+\left(M_{t+1}^{f, D^{*}}-M_{t}^{f}\right) .
$$

The notional supply of bonds is the effective supply, and the notional and effective supply of bonds is therefore

$$
B_{t+1}^{S} \equiv B_{t}+I^{D^{*}}+\left(M_{t+1}^{f, D^{*}}-M_{t}^{f}\right)
$$

The amount of bonds firms seek to supply depends on the amount of investment firms desire to make and the change in money holdings they desire during the period. In the absence of spillovers from other markets into the bond market these are notional investment and the notional change in money holdings during the period, respectively. Since there are no spillovers into the bond market from any of the other markets, equation (8) becomes:

$$
B_{t+1}^{D}-B_{t+1}^{S}=0
$$

Therefore the $\mathrm{BB}$ curve is the effective, as well as the notional bond market equilibrium curve.

However, since the bond market does not clear, firms will not succeed in selling an amount of bonds equal to $\mathrm{B}_{\mathrm{t}+1}^{\mathrm{S}}$ by the end of the period, but only the smaller amount that buyers are willing to purchase, $B_{t+1}^{D}$. Therefore firms cannot borrow all they desire and must either finance the part of the investment they are unable to finance by borrowing by drawing down their money balances below the level they desire and/or reduce their investment expenditures below the level they desire. Therefore, with respect to the impact of realized transactions in the bond market on the other markets, the effective firm sector constraint differs from the notional constraint and is

$$
\left(B_{t+1}^{D}-B_{t}\right) \equiv I^{D^{\prime}}+\left(M_{t+1}^{f, D^{\prime}}-M_{t}^{f}\right) .
$$


Supplies and demands that are effective and not notional are denoted by a prime. Effective investment plus the effective change in money holdings over the period depend on the amount of bonds the firm sector actually succeeds in selling. If firms, when they cannot sell all the bonds they desire, make up any of the shortfall by drawing down money balances, their effective demand for money at the end of the period will be less than their notional demand. If they make any reduction in their investment expenditures, their effective demand for investment goods (effective investment) will be less than their notional demand for investment goods (notional investment). ${ }^{10}$

Therefore the effective demand for investment goods can differ from the notional demand and is

$$
I^{D^{\prime}} \equiv I^{D^{*}}-\alpha\left(B_{t+1}^{S}-B_{t+1}^{D}\right)
$$

$\alpha$ is a spillover coefficient that indicates the fraction of the shortfall in borrowing, which is equal to $\mathrm{B}_{\mathrm{t}+1}^{\mathrm{S}}-\mathrm{B}_{\mathrm{t}+1}^{\mathrm{D}}$, that results in reduced investment. If $\alpha=1$ all of the shortfall in borrowing results in reduced investment expenditures, while if $\alpha=0$ investment remains unchanged and all of the shortfall is made up by firms drawing down their money balances. It will be assumed that firms have sufficient money balances at the beginning of the period in order to be able to do this. The effective aggregate demand for commodities is therefore:

$$
Y^{D^{\prime}} \equiv C^{D}+I^{D^{\prime}}
$$

When there are spillovers from non-market-clearing transactions in the bond market into the commodity market, the commodity market is in equilibrium when

$$
\left(Y^{D^{\prime}}-Y\right)=0
$$

The effective commodity market equilibrium curve, IS', indicates all combinations of $r$ and $\mathrm{Y}$ at which equation (17) holds, and will differ from the notional commodity market equilibrium curve, IS ${ }^{*}$, whenever there are spillovers into the commodity market.

Since firms can choose to finance all or part of the investment that they cannot finance by borrowing by drawing down their money balances, the notional demand for money is not the effective demand. The effective demand for money of the firm sector is

$$
M_{t+1}^{f, D^{\prime}} \equiv M_{t+1}^{f, D^{*}}-(1-\alpha)\left(B_{t+1}^{S}-B_{t+1}^{D}\right)
$$


Since the household sector is able to carry out its transactions plans, the notional household sector demand for money is the effective demand. Therefore the effective demand for money is

$$
M_{t+1}^{D^{\prime}} \equiv M_{t+1}^{h, D}(r, Y)+M_{t+1}^{f, D^{*}}-(1-\alpha)\left(B_{t+1}^{S}-B_{t+1}^{D}\right) .
$$

Substitution of equation (4) into (19) gives us the relationship between the effective and the notional demand:

$$
M_{t+1}^{D^{\prime}} \equiv M_{t+1}^{D^{*}}-(1-\alpha)\left(B_{t+1}^{S}-B_{t+1}^{D}\right) .
$$

When there are spillovers from non-market-clearing transaction in the bond market into the money market, the effective demand for money differs from the notional demand. When this occurs, the money market is in equilibrium, in the sense that the existing stock of money is willingly held, when

$$
M_{t+1}^{D^{\prime}}-M_{t+1}^{S}=0
$$

The effective money market equilibrium curve, LM', indicates all combinations of $r$ and $\mathrm{Y}$ at which equation (21) holds, and will differ from the notional money market equilibrium curve, $\mathrm{LM}^{*}$, whenever there are spillovers into the money market.

Substitution of equations (14) and (18) into (9.1), using equations (4), (5.1), and (16) results in the identity:

$$
\left(Y^{D^{\prime}}-Y\right) \equiv\left(M_{t+1}^{S}-M_{t+1}^{D^{*}}\right)+(1-\alpha)\left(B_{t+1}^{S}-B_{t+1}^{D}\right)
$$

Since equation (22) includes the notional excess demand for money, which differs from the effective excess demand when $\alpha=0$, this implies that Walras' Law does not hold for effective excess demands when the bond market does not clear, regardless of the value of $\alpha$.

\section{THE EFFECTIVE MARKET EQUILIBRIUM CURVES}

We now use the above results to examine the properties of the model when credit rationing takes place, so that the bond market does not clear. Since there are no spillovers into the bond market, the bond market equilibrium curve, $\mathrm{BB}$, is both notional and effective, but below the $\mathrm{BB}$ curve, at which $\left(\mathrm{B}_{t+1}^{\mathrm{S}}-\mathrm{B}_{t+1}^{\mathrm{D}}\right)>0$, so that credit rationing takes place, the effective IS and/or LM curve will differ from the notional curves. 
It should be noted that above the BB curve the model remains unchanged. It is assumed that if the rate of interest is initially above the BB curve, it will instantaneously adjust at the beginning of the period to clear the bond market and that no transactions take place until this has occurred. Therefore the notional excess demands are the effective excess demands and the notional market equilibrium curves are the effective market equilibrium curves. ${ }^{11}$

First of all, substitution of equation (20) into (22) gives us the equation:

$$
\left(Y^{D^{\prime}}-Y\right) \equiv\left(M_{t+1}^{S}-M_{t+1}^{D^{\prime}}\right)
$$

Therefore the effective commodity market equilibrium curve and the effective money market equilibrium curve lie on top of each other, regardless of the value of $\alpha$. Therefore when credit rationing takes place the vector of $r$ and $Y$ at which the existing stock of money is willingly held and the vector at which the commodity market clears are the same, which, of course, differs significantly from the result in the model without credit rationing. The other relationships between the curves depend on the value of $\alpha$, which represents the decisions firm make about how to respond to the inability to borrow all they desire. ${ }^{12}$

\section{Case One: $\alpha=0$}

In this case firms make up all of the shortfall in their borrowing by drawing down money balances. When $\alpha=0$ in equation (15) notional and effective investment are equal, so that the notional aggregate demand for commodities in equation (16) is also the effective aggregate demand. Therefore equation (16) becomes:

$$
Y^{D} \equiv C^{D}+I^{D}
$$

that is, the relationship in equation (3) now holds for effective, as well as notional, demands. With $\alpha=0$ equation (22) becomes:

$$
\left(Y^{D}-Y\right) \equiv\left(M_{t+1}^{S}-M_{t+1}^{D^{*}}\right)+\left(B_{t+1}^{S}-B_{t+1}^{D}\right)
$$

Therefore the notional and effective commodity market equilibrium curve, IS, has the same relationship to the notional $\mathrm{LM}^{*}$ and $\mathrm{BB}^{*}$ (and therefore $\mathrm{BB}$ ) curves as the IS $^{*}$ curve in the model with notional excess demands. This is shown in Figure 3. However, the effective money market equilibrium curve differs from the notional one. Since the notional and effective aggregate demand for commodities are equal, equation (23) becomes:

$$
\left(Y^{D}-Y\right) \equiv\left(M_{t+1}^{S}-M_{t+1}^{D^{\prime}}\right)
$$


Equation (25) implies that, in this case, below the BB curve the effective money market equilibrium curve LM' lies on top of the notional and effective commodity market equilibrium curve IS, as shown in Figure 3. In this case, when credit rationing takes place, the vector or $\mathrm{r}$ and $\mathrm{Y}$ at which the existing stock of money is willingly held differs from the model without credit rationing because it is on the IS curve, rather than on the notional LM curve.

Therefore, at the fixed rate of interest, if firms are initially at a level of output that is off the IS curve, they will adjust their output at the beginning of the period to bring them to the level of output that puts them on the IS curve at that rate of interest. ${ }^{13}$ In this case the simple Keynesian income-expenditure model, with the simple multiplier, will apply, so that the level of output is determined by the saving of the household sector and the (notional) investment of the firm sector, and money does not matter in affecting the level of output during the relevant period.

\section{Case Two: $\alpha=1$}

In this case firms make up all of the shortfall in their borrowing by reducing their level of investment below the level they would have chosen if the bond market had cleared. When $\alpha=1$ in equation (20) the notional and effective demand for money are equal. Therefore equations (22) and (23) both become:

$$
\left(Y^{D^{\prime}}-Y\right) \equiv\left(M_{t+1}^{S}-M_{t+1}^{D}\right)
$$

Equation (26) implies that, in this case, below the BB curve the notional money market equilibrium curve is the effective money market equilibrium curve, but the effective commodity market equilibrium curve, IS', differs from the notional commodity market equilibrium curve IS*. It demonstrates that the IS' curve lies on top of the notional and effective money market equilibrium curve, LM. This is shown in Figure 4. In this case when the rate of interest is at a rate at which credit rationing takes place, the vector of $r$ and $Y$ at which the commodity market is in equilibrium differs from the model without credit rationing because it is on the LM curve, rather than on the notional IS curve.

Therefore, at the fixed rate of interest, if firms are initially at a level of output that is off the LM curve, they will adjust their output at the beginning of the period to bring them to the level of output that puts them on the LM curve at that rate of interest (rather than to the notional IS curve). ${ }^{14}$ Therefore during the current period the level of output is determined by the supply and (notional) demand for money and not by saving and (notional) investment. This is consistent with the simple monetarist model, rather than the simple Keynesian income-expenditure model.

\section{Case Three: $0<\alpha<1$}

In this case some of the shortfall in borrowing is made up by drawing down money balances and some of it results in reduced investment. Once again, the effective IS' and LM' curves lie on top of each other at all vectors of $r$ and Y below the BB curve, as indicated by equation (23). In addition, they lie between the notional commodity market, IS*, and money market, $\mathrm{LM}^{*}$, equilibrium curves. This can be demonstrated as follows: 
In equation (22), since $\alpha<1,(1-\alpha)\left(B_{t+1}^{S}-B_{t+1}^{D}\right)>0$. Therefore at the vectors of $r$ and $\mathrm{Y}$ at which $\left(\mathrm{M}_{\mathrm{t}+1}^{\mathrm{S}}-\mathrm{M}_{\mathrm{t}+1}^{\mathrm{D}^{*}}\right)=0,\left(Y^{\mathrm{D}^{\prime}}-\mathrm{Y}\right)>0$. This implies that at any given rate of interest $\mathrm{Y}$ has to be greater in order to make $\left(Y^{\mathrm{D}^{\prime}}-\mathrm{Y}\right)=0$. Therefore the IS' $=\mathrm{LM}^{\prime}$ curves have to lie to the right of the $\mathrm{LM}^{*}$ curve. Addition of the $\mathrm{C}^{\mathrm{D}}$ term and subtraction of the $\mathrm{Y}$ term from both sides of equation (15), using equations (3) and (16) gives us the identity:

$$
\left(Y^{D^{\prime}}-Y\right) \equiv\left(Y^{D^{*}}-Y\right)-\alpha\left(B_{t+1}^{S}-B_{t+1}^{D}\right)
$$

Since $\alpha>0,-\alpha\left(\mathrm{B}_{\mathrm{t}+1}^{\mathrm{S}}-\mathrm{B}_{\mathrm{t}+1}^{\mathrm{D}}\right)<0$. Therefore at vectors at which $\left(Y^{\mathrm{D}}-\mathrm{Y}\right)=0$. $\left(Y^{\mathrm{D}^{\prime}}-\mathrm{Y}\right)<0$. Therefore, at any given rate of interest, $\mathrm{Y}$ has to be less in order to make $\left(Y^{\mathrm{D}^{\prime}}-\mathrm{Y}\right)=0$. This implies that below the BB curve the IS' $=\mathrm{LM}^{\prime}$ curve must be to the left of the IS $^{*}$ curve.

This is shown in Figure 5. Whether the curve slopes downward to the right, downward to the left, or is vertical depends on the value of $\alpha$ and the parameters determining the slopes of the IS and LM curves. In this case the vector of $r$ and $\mathrm{Y}$ at which firms can sell all they desire and at which the existing money stock is willingly held will be at a point that is neither on the notional IS nor the notional LM curve.

In this case, if initially, at the fixed level of interest, the level of output is not on this curve, firms will adjust their output, at the beginning of the period to bring it to that level. ${ }^{15}$ In this case neither the simple Keynesian income-expenditure, nor the simple Monetarist model holds. Saving and (nominal) investment and the supply and (nominal) demand for money both play a part in determining the level of output, the degree to which they do being determined by the value of $\alpha$. The less the value of $\alpha$, that is, the greater the shortfall in borrowing that is financed by drawing down money balances, the closer the model is to the Keynesian income-expenditure model, while the greater the value $\alpha$, that is, the greater the shortfall in borrowing that is financed by reducing investment, the closer the model is to the monetarist model.

\section{SUMMARY AMD CONCLUSIONS}

We have derived the properties of the simple IS-LM model when credit rationing takes place, so that non-market-clearing transactions take place and are finalized in the bond market at interest rates less than the market-clearing rate. It has been shown that the effective market equilibrium curve for either the commodity market, or the money market, or both will differ from the notional market equilibrium curve under such conditions. We have, for the sake of brevity not included the theoretical possibility of transactions taking place and being finalized in the bond market at interest rates above the market-clearing rate, at which households would be unable to lend all they desire, since this theoretical curiosity appears to have little, if any, relevance to observed behavior in actual market economies.

In recent years, due to the development of the new Keynesian economics, there has been a significant degree of interest in the use of sticky-price models in macroeconomic modeling. The present paper shows how the effects of sticky prices 
in the bond market can be incorporated into the simple IS-LM model using the analytical tools based on Clower's dual decision hypothesis. After Clower [4] introduced the dual decision hypothesis to the literature, a large body of literature based on it was generated. But eventually interest in it very seriously declined, so that Clower [5, p. 154] has stated, "Since the 1980s the dual decision hypothesis seems to have dropped out of sight... ." Our results demonstrate the continuing relevance of the dual decision hypothesis in models in which sticky prices prevent markets from clearing continuously, so that non-market-clearing transactions can take place and be finalized. Clower's fundamental insight that when non-market-clearing transactions take place and are finalized realized transactions enter the relevant constraints of the transactors continues to be valid and relevant.

\section{ENDNOTES}

1. We would like to thank two anonymous referees for helpful comments.

2. See, for example, McCaleb and Sellon [9, pp. 403-408]. It should be noted that the curve can slope either upward or downward, depending on the values of the parameters.

3. The paper also makes use of material from two papers by Buck $[2 ; 3]$.

4. It should be noted that the notional supplies, demands, constraints, and market equilibrium curves are notional only with respect to those markets that are specified in the model; that is, the commodity, bond, and money markets. The implicit labor market underlying the model is in excess supply except at the "full employment" level of output. The notional quantities in the model are therefore, to be precise, based on the assumption that transactors expect to succeed in carrying out their transactions plans in those markets that are explicitly specified in the model.

5. It should be noted, however, that $Y$, which represents realized output, also represents the aggregate supply of commodities, as was explained above.

6. At all points above and to the right of the $\mathrm{IS}^{*}$ curve and below and to the right of the $\mathrm{LM}^{*}$ curve $\left(\mathrm{Y}^{\mathrm{D}^{*}}-\mathrm{Y}^{\mathrm{S}^{*}}\right)<0$ and $\left(\mathrm{M}_{\mathrm{t}+1}^{\mathrm{D}^{*}}-\mathrm{M}_{\mathrm{t}+1}^{\mathrm{S}^{*}}\right)>0$. Therefore between the curves for each $Y$ there is a value of $r$ at which $\left(B_{t+1}^{D^{*}}-B_{t+1}^{S^{*}}\right)=0$. For similar reasons the $\mathrm{BB}^{*}$ curve must be between the $\mathrm{IS}^{*}$ and $\mathrm{LM}^{*}$ curves at points to the left of the intersection of the IS ${ }^{*}$ and $\mathrm{LM}^{*}$ curves.

7. An analysis of the factors that can cause credit rationing to occur must be beyond the scope of the present paper. However this could be caused by asymmetric information in the credit market or by the government imposing an interest rate ceiling below the equilibrium rate.

8. This can be caused by a change in the supply or demand for bonds during the current period, or by the government imposing an interest ceiling below the equilibrium rate.

9. In the simple IS-LM model it is frequently assumed that transactions can also take place and be finalized when the commodity market does not clear, so that unintended investment or disinvestment takes place. The implications of this are analyzed in two papers by Buck [2;3], but for the sake of brevity must be beyond the scope of the present paper.

10. Both notional and effective investment are intended investment. Since the commodity market continuously clears, there is no unintended investment. The 
effective investment is the intended investment once the effects of spillovers are accounted for.

11. In order for non-market-clearing transactions to take place above the BB curve, the rate of interest would have to remain above the BB curve during the period and transactions would have to take place and be finalized at that rate. As a result households would not succeed in lending all they desire, that is, not succeed in buying all the bonds they desire. This would require them to either increase their money holdings above the level they desire and/or increase their consumption above the level they desire. The results for the effective IS and LM curves would be analogous to the results for the credit rationing case. Since situations at which lenders are unable to lend all they desire do not appear to arise, this case is a theoretical curiosity only.

12. Since household are able to carry out their transactions plans, they respond to changes in $r$ and $Y$ in the same manner as when markets clear, so that their decisions do not affect which case holds.

13. At that level of output firms are holding less than their notional demand for money, but have made the amount of investment they had desired. Households, of course, in this and the other two cases, have succeeded in carrying out their desired transactions.

14. At that level of output firms are holding their notional demand for money, but have made a smaller amount of investment than they had desired.

15. At that level of output firms are holding less than their notional demand for money and have made a smaller amount of investment than they had desired.

\section{REFERENCES}

Barro, Robert J., and Herschel I. Grossman. Money, Employment, and Inflation. Cambridge: Cambridge University Press, 1976.

Buck, Roland. "The Bond Market in the IS-LM Model: A Non-Market-Clearing Approach." The Journal of Economics 18 (1992): 77-85.

"The Simple IS-LM Model Under Alternative Methods of Financing Unintended Investment." Kentucky Journal of Economics and Business 21 (2002): 32-53.

Clower, Robert W. "The Keynesian Counterrevolution: A Theoretical Appraisal," in F. H. Hahn and F. P. R. Brechling, eds., The Theory of Interest Rates. London: Macmillan and Co., Ltd., 1965, 103- 125.

"Dual Decision Hypothesis," in Thomas Cate, Geoff Harcourt, and David C. Colander, eds., An Encyclopedia of Keynesian Economics. Brookfield, Vt: Edward Elgar, 1997, 154-155.

Fischer, Stanley. "Interview," in Brian Snowdon, Howard Vane, and Peter Wynarczyk, eds., A Modern Guide to Macroeconomics: An Introduction to Competing Schools of Thought. Brookfield, Vt.: Edward Elgar, 1994, 32-41.

Grossman Herschel I. "Money, Interest, and Prices in Market Disequilibrium." Journal of Political Economy 79 (Sept.-Oct. 1971): 943-61.

Hicks, John R. "Mr. Keynes and the 'Classics': A Suggested Interpretation." Econometrica 5 (April 1937): 147-59.

McCaleb, Thomas S., and Gordon H. Sellon, Jr. "On the Consistent Specification of Asset Markets in Macroeconomic Models.” Journal of Monetary Economics 6 (July 1980): 401-417. 


\section{DIAGRAMS}

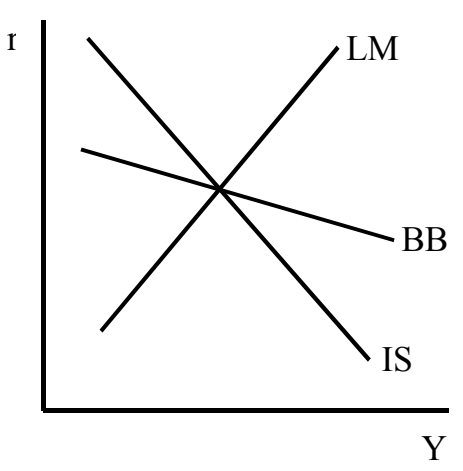

FIGURE 1

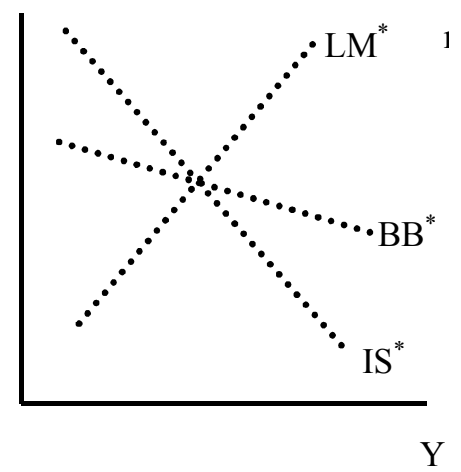

FIGURE 2

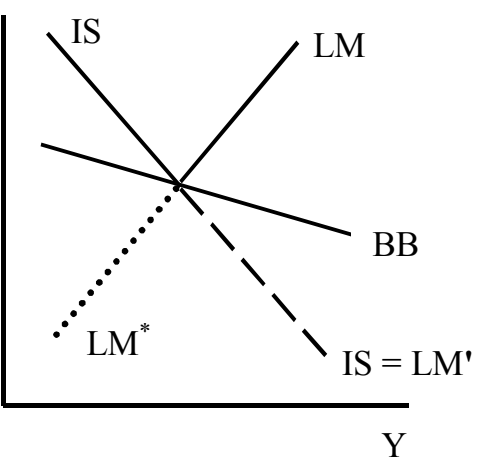

FIGURE 3

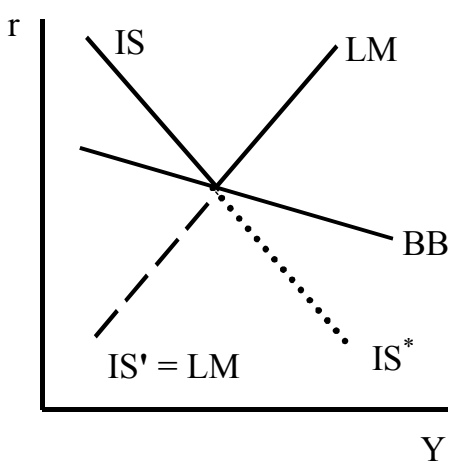

FIGURE 4

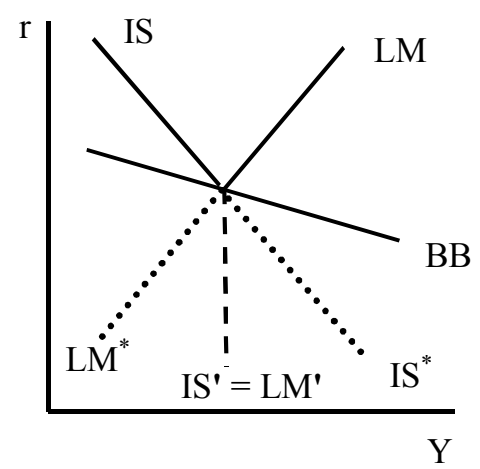

FIGURE 5

In all of the diagrams the following rules apply:

Market equilibrium curves that are notional and effective are shown as solid lines.

Market equilibrium curves that are notional only and not effective are shown as dotted lines.

Market equilibrium curves that are effective only and not notional are shown as lines with short dashes. 
Southwestern Economic Review

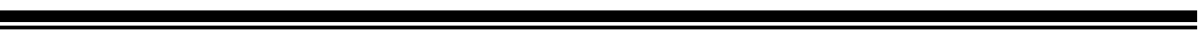

156 